\title{
(RE)CONSTRUCTION OF THE EDUCATIONAL EXPERIENCE IN FUTURE TEACHERS' VISIONS OF THEIR PROFESSIONAL ACTIVITY
}

\author{
Erika Masiliauskienè \\ Šiauliai University, Lithuania \\ Jurgita Lenkauskaitė \\ Šiauliai University, Lithuania
}

\begin{abstract}
The article presents the results of a scientific research obtained after the phenomenological content analysis of future teachers' visions of their professional activity. In future teachers' visions of their professional activity the representations of the (re)construction of the educational experience are clearly observed. The informants of the research reflecting on their experience of learning at school and the vision of their professional pedagogical activity reveal the content of pedagogical activity and its transformations.

The article analyses how the person's relationship to significant "others" constructs the knowledge about the teacher's role. The "sub-world" of the educational experience, that is experienced and internalized by future teachers during the period of their learning at school and (re)constructed during their pedagogical studies is, in fact, an integral reality.

Thus the (re)construction of the previously internalized educational experience is revealed as the new content of the educational experience arises. The results of the research permit to state that future teachers in the processes of the (re)construction of the educational experience do not demonstrate a strong identification with the internalized content of pedagogical activity/educational experience during their learning at school.

The problem question of the research - what content of the educational experience at school do future teachers reflect on and how is the (re)constructed educational experience reflected on or recognized in the visions of professional activity.
\end{abstract}

Keywords: educational experience, professional vision, future teachers.

\section{Introduction}

The reconstruction of teacher training in Lithuania today is a national priority. For that purpose, the forces of the specialists in various fields (as well as international experts) are brought together and their actions are focused on various parameters of the quality of teacher training: the concentration of scientific pedagogical staff in national teacher training centres to strengthen research-based teacher training; the improvement of the system of selection for pedagogical studies; the structure and content of the competences needed to develop are reviewed and updated, etc. Alongside with the upgrading of the system of future 
Masiliauskiene \& Lenkauskaite, 2020. (Re)Construction of the Educational Experience in Future Teachers'Visions of their Professional Activity

teachers' training, the system of the improvement of the qualification of teachers is also being changed. The concept of professional growth is established, when there is a very clear relation between the links of teacher training and independent pedagogical activity, i.e. professional growth begins in the first year of pedagogical studies and continues throughout the whole period of pedagogical professional activity. The curriculum of general education also began to be updated, the realization of which will require the teacher's extremely high-quality and innovative acting in the educational reality. These processes require responsible and well-thought political decisions and clear economic justification creating reliable instruments of forecasting the need for teachers, they also require a clear understanding of sociocultural and socioeducational context, in which and for which a future teacher will be trained. Consequently, one of the components of the formation of such understanding is knowledge based on scientific research and knowing about the personality changes of the future teachers studying in pedagogical studies (Uerz, Volman, \& Kral, 2017; Lenkauskaite, 2019, etc.) and the meanings of the teacher's profession and pedagogical activity (Cibulskas \& Žydžiūnaite, 2012). In this context, the authors of the research concretize the problem of the research formulating the problem question of the research: what content of the educational experience do future teachers reflect on and how is the (re)constructed educational experience reflected on or recognized in the visions of professional activity.

Future teachers' professional visions are related to the meanings of culture and context, which are important in order to perceive the social processes taking place in the field of pedagogical activity (Ho \& Tan, 2013). The sociocultural context determines attitudes, beliefs, and thinking. It means that the future teacher's active position in these environments and activities where he/she finds himself/herself is very important, consequently, the future teacher has an opportunity to actively (re)construct the educational experience.

Reflecting on the experiences of teaching/learning at school becomes a basis for the (re)construction of the educational experience creating personal visions of the professional pedagogical activity (Lenkauskaite \& Masiliauskiené, 2019). Various scientists (Ho \& Tan, 2013; Uerz, Volman, \& Kral, 2017; Lenkauskaite, 2019; Lenkauskaite \& Masiliauskienè, 2019, etc.) point out that for the (re)construction of the educational experience, the future teacher's ability to critically evaluate experiences focusing on the things that should be or could be is especially important. The contents of the (re)construction of the educational experience can cover various aspects such as teacher-student relationship, creation of a meaningful educational environment, ensuring the quality of education, focus on the success of student's teaching/learning, structure of professional knowledge and understanding of its importance, attitudes towards teaching and learning, etc. (Ho \& Tan, 2013). 
Research object - (re)construction of the pedagogical experience. The aim of the research is to reveal the contents of the (re)construction of future teachers' pedagogical experience in future teachers' visions of their pedagogical activity.

The methods of the research - the analysis of scientific literature and interview with future teachers. The participants of the research - the research included students of university pedagogical studies, future teachers of preschool education, pre-primary education, subject teachers.

\section{(Re)construction of the pedagogical experience as a basis of the creation of future teachers' professional vision}

The processes of the (re)construction of the pedagogical experience are inevitably related to the change of the teacher's role in the modern society. The requirement to be an innovator becomes the essential challenge for the teacher. Not by accident in the previous research on teacher training (Maeda \& Asada, 2016) the main focus was on the teacher's knowledge or beliefs. Recently the scientists (Blömeke et al., 2015; Maeda \& Asada, 2016; Lenkauskaitė \& Masiliauskienè, 2019, etc.) have been increasingly focusing on the learning of the teacher himself/herself, his/her constant improvement, the ability to reflect on his/her pedagogical activity, to accept individual responsibility and develop collective responsibility for educational outcomes, to create and develop authentic teaching/learning practice, to look for new educational strategies, etc. In order to accept such challenges and act respectively, it is necessary to constantly rethink various pedagogical experiences, to (re)construct them and create an authentic vision of pedagogical professional activity.

A professional vision (Goodwin, 1994; van Es \& Sherin, 2002; Seidel \& Sturmer, 2014, etc.) is understood as an ability to notice a practice that is necessary acting with respective sociocultural groups, responding to the context, in which the action takes place. A professional vision comprises knowledge that allows to understand 1) what pedagogical experiences were experienced by future teachers and 2) how they (re)construct the aforementioned experiences creating the vision of their pedagogical activity. It is important for future teachers to take up an active role analysing the experiences they have and to (re)construct them foreseeing the priority action schemes of the pedagogical activity (Meshede, Fiebranz, Möller, \& Steffensky, 2017).

It should be noted that pedagogical experiences are experienced through various social interactions with significant "others". The scientists (Ho \& Tan, 2013) also point out that the (re)construction of the pedagogical experience and the creation and contents of the professional vision can be "limited", when a future teacher restricts himself/herself with the reflection only on certain experience (for example, learning at school). 
Masiliauskiene \& Lenkauskaite, 2020. (Re)Construction of the Educational Experience in Future Teachers'Visions of their Professional Activity

It can be noticed that the analysis of the pedagogical experiences appeals to the relations of the research to the philosophy of pragmatism. Namely the representatives of the philosophy of pragmatism (W. James, J. Dewey) support the idea that "experience is the most important and determining factor in perceiving the world and planning the future" (Duoblienè, 2006, p. 16). Referring to the philosophy of pragmatism, education is based on the analysis of the acquired experience as an important element further designing the processes of education and training.

The construction of experience and educational reality is closely related to the opportunities and need for reconstruction, which can be expressed in the educational process by designing changes, implementing innovations, and foreseeing improvements. The benefits of the reconstruction of education was especially emphasized by social reconstructionists, who highlighted the necessity to teach the younger generation to understand the illnesses of society and to create projects enabling global change (Duoblienè, 2006). Future teachers personally contribute to the (re)construction of educational reality by creating their own visions of the pedagogical activity, thus striving to respond to the challenges posed by a changing society to education, to organize an innovative teaching process that is favourable to the new generation of students.

\section{Research methodology}

To obtain the data of the empirical research a written survey was conducted. 23 students of one of the universities of Lithuania who are preparing to become teachers and who voluntarily agreed to participate in the survey, participated in it and presented their professional visions. The research took place in March-April, 2019. During the survey the students were asked to freely describe how they imagine their future pedagogical activity and what has an impact on their vision.

The empirical research is based on the theory of pragmatism emphasizing the importance of experience (Dewey, 2013) and the approach of the construction of social reality (Berger \& Luckmann, 1999). The constructivist approach to experience also presupposes the possibility of its reconstruction, which was important revealing authentic professional visions of future teachers.

The results of the empirical research were analysed applying a phenomenological approach (see Mickūnas \& Stewart, 1994) highlighting the meanings constructed in future teachers' professional visions. A qualitative content analysis applied in the research gives valuable information for the science and practice of education, helps to form the attitude to a new object or topic of the research, to evaluate the phenomenon under investigation (Žydžiūnaitė \& Sabaliauskas, 2017). The research results are structured distinguishing the topics, categories, and subcategories that are predominant in professional visions and 
reflect the (re)construction of the educational experience, and also presenting authentic illustrative statements of the informants.

Following the ethics of research the confidentiality of the research participants was assured. Presenting their professional visions they were not asked to indicate their name or surname or other personal data. The professional vision of every participant was encoded and only its number was presented in the data of the article (e.g., PV (pedagogical vision) 5).

\section{Participants of the (re)construction of the educational experience as significant "others"}

Analysing the professional visions of future teachers, the network of the "bearers" of social knowledge related to the (re)construction of the educational experience was distinguished. Referring to the research conducted by P.L. Berger, T. Luckmann (1999), the "bearers" of social knowledge are called significant "others". Consequently, one of the features describing the process of the (re)construction of the educational experience - significant "others" in the process of choosing the teacher's profession and significant "others" while studying in pedagogical studies. The relationship between the research informants and significant "others" is characterised with a dual nature and content, as a consequence of which the educational experience is also respectively (re)constructed.

The internalization of the "sub-worlds" created by significant "others" forms a primary social knowledge about the teacher's professional activity. However, at the same time significant "others" bear a social message about how the educational experience could/should be modelled. Having conducted a phenomenological content analysis of future teachers' professional visions, it was revealed that two groups of the "bearers" of social knowledge - significant "others" - are important for the formation of the research informants' social knowledge about the pedagogical activity and the (re)construction of the educational experience. The first group - people who played the strongest role in the formation of the understanding about the pedagogical activity and educational experience. These are significant "others" in the process of choosing the profession of a teacher. The second group - significant "others", whose role is mostly observed in the stage of pedagogical studies: Group I: 1) parents; 2) other family members; 3) accidentally met people; 4) teachers who taught them; 4) friends. Group II: 1) lecturers of a higher education institution; 2) mentors of the pedagogical practice; 3) peer teachers.

The relationship between the future teachers and significant "others" in the process of choosing the profession creates the conditions to take over the "subworlds" of the pedagogical activity created by them. In these "sub-worlds", the 
Masiliauskiene \& Lenkauskaite, 2020. (Re)Construction of the Educational Experience in Future Teachers' Visions of their Professional Activity

factor of subjectivity is evident both attributing the features to the teacher's role and particularly characterizing the requirements for the educational experience. Consequently, in the future teachers' professional visions, parents, other family members (siblings, close relatives), accidentally met people, teachers who taught them are significant "others", who are the most strongly emphasized since they have created the conditions for the internalization of the "sub-worlds" of the pedagogical activity understood and created by them:

People encourage me, motivate me to pursue future pedagogical activity (PV-9-2).

Later, acquiring more knowledge and experience, as the circle of significant "others" is expanding, the future teachers' social knowledge about the teacher's activity is also being expanded, the educational experience is being (re)constructed. The essential turning point takes place having started studies in pedagogical programmes. In this context, the most important role is played by the pedagogical staff of the higher education institution, i.e., the lecturers educating the future teachers:

My vision of the professional activity is shaped by the lecturers I met during my studies, who provide knowledge of what a teacher should be, what attitudes he/she should follow, and what methods he/she should use in his/her work (PV-21-1).

The mentors of the pedagogical practice in educational institutions and peer teachers are more weakly emphasized but not less significant. They contribute to the (re)construction of the educational experience, when the future teachers face the real (not only imaginary or designed) context of the pedagogical activity.

The domination of significant "others" in the process of the pedagogical studies reflects how intensely the identification with the teacher's role and the norms assigned to it takes place in the process of the internalization of the educational experience. Consequently, when the future teachers start studies, acquire new pedagogical knowledge and experience, the process of the (re)construction of the educational experience takes place the most intensely as well. When the experience of learning at school is newly evaluated, the "subworlds" of the pedagogical activity of significant "others" internalized in the process of choosing the profession are newly interpreted. In the process of the (re)construction of the educational experience, the meanings of the educational experience are created as the expectations for personal independent pedagogical activity after completing the studies. The meanings created by the future teachers are supported and legitimized in various contexts: in the relationships with significant "others" - lecturers, mentors, peer teachers. It should be noted that the role of parents or other family members becomes especially weakly expressed. 


\section{Construction of the pedagogical experience taking over good practice}

The future teachers writing the visions of their professional activity present empirically important information related to the construction of their pedagogical experience taking over good practice. The obtained results of the research have been grouped into categories and subcategories, their illustrative statements have been presented (see Table 1).

Table 1 Construction of the pedagogical experience taking over good practice

\begin{tabular}{|c|c|c|}
\hline Category & Sub-category & Illustrative statements \\
\hline \multirow[t]{2}{*}{$\begin{array}{l}\text { Teacher- } \\
\text { student } \\
\text { relationship }\end{array}$} & $\begin{array}{l}\text { Positive } \\
\text { communication and } \\
\text { collaboration }\end{array}$ & $\begin{array}{l}\text { "I would like to communicate with students warmly } \\
\text { and kindly, the way my beloved teacher } \\
\text { communicated with me" (PV-7-7) }\end{array}$ \\
\hline & $\begin{array}{l}\text { Mutual respect and } \\
\text { confidence }\end{array}$ & $\begin{array}{l}\text { "It is important that the teacher and the student } \\
\text { respect each other" (PV-1-8) }\end{array}$ \\
\hline \multirow{3}{*}{$\begin{array}{l}\text { Organization } \\
\text { of the } \\
\text { educational } \\
\text { process }\end{array}$} & $\begin{array}{c}\text { Diversity of } \\
\text { teaching/learning } \\
\text { methods }\end{array}$ & $\begin{array}{c}\text { "[...] used many methods, which help me up to now } \\
{[\ldots] "(\text { PV-1-8) }}\end{array}$ \\
\hline & Freedom to choose & $\begin{array}{l}\text { "The child's freedom to choose what is relevant to } \\
\text { him/her" (PV-2-10) }\end{array}$ \\
\hline & $\begin{array}{l}\text { Independence solving } \\
\text { problems }\end{array}$ & $\begin{array}{l}\text { "[...] for children themselves to think how they } \\
\text { could solve it and choose the best option" (PV-3-17) }\end{array}$ \\
\hline \multirow{2}{*}{$\begin{array}{l}\text { Teacher's } \\
\text { professional } \\
\text { image }\end{array}$} & Objectivity & “The teacher’s objectivity is important” (PV-11-4) \\
\hline & $\begin{array}{l}\text { Proper preparation } \\
\text { for work }\end{array}$ & $\begin{array}{l}\text { "[...] where I saw the teacher, who was always } \\
\text { ready and smart [...]” (PV-8-5) }\end{array}$ \\
\hline
\end{tabular}

The research has shown that future teachers writing their personal visions of professional activity reveal what good educational experience they would take over constructing particular priorities of their pedagogical activity. The informants point out that in their pedagogical activity they would pay special attention to the relationships between the participants of education, the peculiarities of the organization of the educational process, and the formation of the teacher's professional image. The content of the school experiences of future teachers reveals that the research participants identify the importance to establish a close and solid relationship between the teacher and the student, which is developed through a mutual desire to communicate and cooperate in the educational institution (especially in the classroom) as an exceptional component of pedagogical professional activity. The positivity of teacher-student relationship is closely related to the peculiarities of the organization of the educational process. The future teachers point out that in the context of the organization of the educational process, the most important good practice to be communicated is related to the teacher's abilities to apply various teaching/learning methods 
Masiliauskiene \& Lenkauskaite, 2020. (Re)Construction of the Educational Experience in Future Teachers' Visions of their Professional Activity

especially the ones that encourage the learner's activeness, students' teamwork, and the integration of educational games in the educational process. The future teachers relate the teacher's professional image to the teacher's objectivity and the teacher's constant and proper preparation for work (for example, work in the classroom).

\section{Reconstruction of the pedagogical experience transforming the reality of education}

In their visions of professional activity, future teachers present empirically significant knowledge about the reconstruction of the pedagogical experience they expect when the former experience is abandoned and the new experience is created. The obtained results of the research have been presented in Table 2.

Table 2 Reconstruction of the pedagogical experience abandoning the former experience and creating the new experience

\begin{tabular}{|c|c|c|}
\hline Category & Sub-category & Illustrative statements \\
\hline \multirow{2}{*}{$\begin{array}{l}\text { Reconstruction } \\
\text { of the } \\
\text { experience } \\
\text { abandoning } \\
\text { the former } \\
\text { experience }\end{array}$} & $\begin{array}{c}\text { Students' } \\
\text { demotivation }\end{array}$ & $\begin{array}{l}\text { "I would change it so that children would not be } \\
\text { judged"(PV-20-3) }\end{array}$ \\
\hline & $\begin{array}{l}\text { Assessment that } \\
\text { inhibits students' } \\
\text { improvement }\end{array}$ & $\begin{array}{l}\text { "The assessment is made but nobody is told why } \\
\text { the assessment is like this or that, and what should } \\
\text { be done" } \\
\text { (PV-21-9). }\end{array}$ \\
\hline \multirow{4}{*}{$\begin{array}{l}\text { Reconstruction } \\
\text { of the } \\
\text { experience } \\
\text { creating the } \\
\text { new } \\
\text { experience }\end{array}$} & $\begin{array}{c}\text { Diversity of } \\
\text { teaching/learning } \\
\text { methods }\end{array}$ & $\begin{array}{l}\text { "I would change it bringing in some newer } \\
\text { methods" (PV-10-2). }\end{array}$ \\
\hline & $\begin{array}{l}\text { Actualization of the } \\
\text { contents of } \\
\text { teaching/learning }\end{array}$ & $\begin{array}{l}{[. . .] \text { take over such aspects of the organization of }} \\
\text { teaching/learning process" (PV-6-7). }\end{array}$ \\
\hline & $\begin{array}{l}\text { Diversity in the } \\
\text { assessment of the } \\
\text { educational } \\
\text { achievements and } \\
\text { progress }\end{array}$ & $\begin{array}{l}\text { "Assess not only with tests but also by assigning } \\
\text { creative tasks” (PV-20-8). }\end{array}$ \\
\hline & $\begin{array}{l}\text { Diversity of } \\
\text { educational } \\
\text { environments }\end{array}$ & $\begin{array}{l}\text { "To look for new environments, for example, to } \\
\text { go outside the school” (PV-12-9). }\end{array}$ \\
\hline
\end{tabular}

The process of the reconstruction of the pedagogical experience is the most closely related to the professional aspirations to change the educational practice giving up such a professional position of the teacher, taking which the teacher demotivates students constantly telling them that they would not pass examinations, would not perform tests properly, etc. At the same time the future 
teachers show their denial, i.e. point out that in their professional activity they have a goal to change the assessment of educational outcomes and progress, when the assessment becomes the instrument for punishment but not for the student's improvement. Another aspect of the (re)construction of the pedagogical experience - a change in the ways, in which educational achievement and progress are assessed, by abandoning testing - is also emphasized.

The reconstruction of experience by creating the new experience is the most significantly related to the priority to apply as various as possible teaching/learning methods and to actualize the contents of education so that knowledge gained at school would be related to the situations of everyday life. The future teachers understand that to achieve these goals the diversity of educational environments is necessary, as well as different assessment of educational achievement (e.g., through creative-project activities).

\section{Conclusions}

Summing up, it is possible to state that the content of the relationship with significant "others", which is mostly emphasized by future teachers in their visions of professional activity, includes motivating for the choice of the teacher's profession and the chosen pedagogical professional activity. This content is mostly expressed in the relationship of the future teachers with significant "others" - parents, other family members, and lecturers of a higher education institution. Parents, other family members, and lecturers in different ways create the conditions supporting the meanings of the pedagogical activity, important for themselves and others, constructed by the future teachers, and allow legitimizing them in different sociocultural contexts (home environment, university studies).

The content of the (re)construction of the pedagogical experience reveals which aspects of the pedagogical activity the future teachers consider as priority. Consequently, (re)constructing the experiences they have, future teachers identify the most important elements of their pedagogical activity such as the organization of the educational process using a variety of innovative educational methods, seeking to develop a different practice of the assessment of educational achievement and progress, establishing a teacher-student relationship that ensures the student's social and emotional security, motivates the student for improvement, creates the conditions for the student to be an active participant of the educational process (to make decisions, to accept responsibility, etc.). 
Masiliauskiene \& Lenkauskaitè, 2020. (Re)Construction of the Educational Experience in Future Teachers'Visions of their Professional Activity

\section{References}

Berger, P.L., \& Luckmann, T. (1999). Socialinis tikrovès konstravimas [The Social Construction of Reality]. Vilnius: Pradai.

Blömeke, S., Gustafsson, J.E., \& Shavelson, R.J. (2015). Beyond dichotomies: Competence viewed as a continuum. Zeitschrift für Psychologie, 223, 3-13. DOI: http://dx.doi.org/10.1027/2151-2604/a000194

Cibulskas, G., \& Žydžiūnaitè, V. (2012). Lyderystès vystymosi mokykloje modelis [The Model of Leadership Development at School]. Vilnius: ŠAC.

Dewey, J. (2013). Demokratija ir ugdymas [Democracy and Education]. Klaipeda: Baltic printing house.

Duoblienè, L. (2006). Šiuolaikine ugdymo filosofija [Contemporary Philosophy of Education]. Vilnius: Tyto alba.

Goodwin, Ch. (1994). Professional Vision. American Anthropologist, 96(3), 606-633. Retrieved from http://pages.ucsd.edu/ johnson/COGS102B/Goodwin94.pdf

Ho, K.F., \& Tan, P. (2013). Developing a Professional Vision of Classroom Practices of a Mathematics Teacher: Views from a Researcher and a Teacher. Teaching Education, 24(4), 415-426. DOI: https://doi.org/10.1080/10476210.2012.727179

Lenkauskaite, J. (2019). Power Relations of the Participants of the Educational Process and their Transformation in the Perspective of the Learning Paradigm. Society. Integration. Education: Proceedings of the International Scientific Conference, 2(3824), 280-290.

Lenkauskaite, J., \& Masiliauskienè, E. (2019). Expectations of the Transformation of Power Relationships in the Educational Process: Future Teachers' Vision. EDULEARN Proceedings, 9181-9190. DOI: 10.21125/edulearn.2019.2268

Maeda N., \& Asada, T. (2016). Identifying Teacher's Professional Vision in Elementary School Teaching. ECER 2016. Retrieved from https://www.eera-ecer.de/ecer-programmes/ conference/21/contribution/38779/

Meschede, N., Fiebranz, A., Möller, K., \& Steffensky, M. (2017). Teachers’ Professional Vision, Pedagogical Content Knowledge and Beliefs: on Its Relation and Differences Between Pre-Service and In-Service Teachers. Teaching and Teacher Education, 66, 158-170. DOI: https://doi.org/10.1016/j.tate.2017.04.010

Mickūnas, A., \& Steward, D. (1994). Fenomenologine filosofija [Phenomenological Philosophy]. Vilnius: Baltos lankos.

Seidel, T., \& Stürmer, K. (2014). Modeling and Measuring the Structure of Professional Vision in Preservice Teachers. American Educational Research Journal, 51(4), 739-771. DOI: https://doi.org/10.3102/0002831214531321

Uerz, D., Volman, M., \& Kral, M. (2018). Teacher Educators' Competences in Fostering Student Teachers' Proficiency in Teaching and Learning with Technology: an Overview of Relevant Research Literature. Teaching and Teacher Education, 70, 12-23. DOI: https://doi.org/10.1016/j.tate.2017.11.005

van Es, E.A., \& Sherin, M.G. (2002). Learning to Notice: Scaffolding New Teachers' Interpretations of Classroom Interactions. Journal of Technology and Teacher Education, 10(4), 571-596.

Žydžiūnaitè, V., \& Sabaliauskas, S. (2017). Kokybiniai tyrimai: principai ir metodai [Qualitative research: principles and methods]. Vilnius: Vaga. 